\title{
PENGARUH FIRM SIZE TERHADAP LEVERAGE PADA PERUSAHAAN MANUFAKTUR PUBLIK INDONESIA PERIODE 2013-2017
}

\author{
Sisca Shanthana L. ${ }^{*}$, Sautma Ronni Basana ${ }^{2}$ \\ 1,2 Program Finance \& Investment, Program Studi Manajemen \\ Fakultas Bisnis dan Ekonomi, Universitas Kristen Petra \\ Jl. Siwalankerto 121-131, Surabaya 60236 \\ E-mail: ${ }^{1} m 37415066 @ j o h n . p e t r a . a c . i d ;{ }^{2}$ sautma@petra.ac.id \\ *Penulis korespondensi
}

\begin{abstract}
ABSTRAK
Keberlangsungan perusahaan memerlukan sistem pendanaan yang memadai dan struktur pendanaan untuk dapat menjaga aktivitas. Perusahaan yang berhasil mengelola struktur modal yang dapat mengelola biaya yang dikeluarkan dengan mampu menghasilkan laba perusahaan. Penelitian ini bertujuan untuk meneliti pengaruh firm size terhadap Leverage Perusahaan Manufaktur yang tercatat di Bursa Efek Indonesia periode 2013-2017. Sampel yang digunakan adalah 42 perusahaan manufaktur publik pada periode 2013-2017. Metode analisis data dilakukan dengan menggunakan regresi data panel dengan fixed effect model. Hasil penelitian ini menunjukan size dan profitabilitas memiliki pengaruh yang signifikan terhadap leverage perusahaan manufaktur yang tercatat di Bursa Efek Indonesia periode 2013-2017.
\end{abstract}

Kata kunci: Ukuran perusahaan, keputusan pendanaan, utang, aset tetap, profitabilitas, usia perusahaan, umur perusahaan, perusahaan manufaktur.

\begin{abstract}
The sustainability of a company requires an adequate funding system and a funding structure to be able to maintain activities. Companies that successfully manage a capital structure that can manage costs incurred by being able to generate company profits. This study aims to see the effect of firm size on leverage of manufacturing companies listed on the Indonesia Stock Exchange period year 2013 to 2017. The samples are forty-three manufacturing companies listed on the Indonesia Stock Exchange period year 2013 to 2017. Methods of data analysis was performed using panel data regression with fixed effect model. The results of this analysis showed that size and profitability have a significant effect on corporate leverage decision of manufacturing companies listed on the Indonesia Stock Exchange period year 2013-2017.
\end{abstract}

Keywords: Leverage, firm size, asset tangibility, profitability, manufacturing company.

\section{PENDAHULUAN}

Mempertahankan kelangsungan hidup perusahaan merupakan suatu kewajiban yang harus dilakukan oleh perusahaan, sehingga perusahaan dituntut untuk terus-menerus meningkatkan produksi secara efektif dan efisien. Hal ini tentu saja tidak dapat dipisahkan dari aktivitas pendanaan. Aktivitas pendanaan tercermin dalam struktur modal suatu perusahaan yang merupakan komposisi perubahan utang, perubahan ekuitas, maupun perubahan laba ditahan.

Leverage adalah aktivitas pendanaan yang menggunakan biaya tetap (Huyghebaert, 2006). Leverage merupakan pilihan, tidak ada perusahaan yang dituntut untuk melakukan utang. Perusahaan dapat membiayai operasi dan pengeluaran modal dari sumber internal dan penerbitan saham. Leverage digunakan dengan harapan dapat meningkatkan pengembalian kepada peme- 
gang saham. Dittmar (2004) menunjukkan bahwa utang adalah salah satu alat yang digunakan oleh perusahaan untuk meningkatkan modal dan keuntungan. Tongurai (2015), mengatakan leverage positif terjadi ketika perusahaan memperoleh dan memanfaatkan dana yang lebih besar dari pengorbanan biaya tetap yang dibayarkan. Leverage dapat meningkatkan harga saham perusahaan selama periode peningkatan pendapatan operasional tetapi juga menambah risiko bagi pemegang saham dan kreditur karena adanya tambahan kewajiban bunga.

Keputusan struktur modal terutama dalam kebijakan utang suatu perusahaan harus dilakukan secara tepat sesuai dengan keadaan keuangan perusahaan (Raviv, 1991). Financial distress, kebangkrutan dan likuidasi merupakan akibat dari kelalaian dalam melakukan pertimbangan yang tepat terkait keputusan struktur modal (Suhaila et al., 2008).

Firm size menjadi salah satu variabel penting yang digunakan dalam menjelaskan tingkat leverage perusahaan. Perusahaan dengan size besar lebih terdiversifikasi dan lebih mudah mengakses pendanaan melalui capital market (Pandey, 2004). Sementara itu, biaya yang dikeluarkan untuk emisi saham dan obligasi dapat menghalangi perusahaan kecil dalam upaya melakukan pendanaan dalam capital market karena adanya keterbatasan dana (Ezeoha, 2008). Oleh sebab itu, besar kecil perusahaan berpengaruh terhadap keputusan penggunaan utang atau leverage.

Menurut Antoniou et al. (2002), firm size adalah ukuran dari suatu perusahaan yang dilihat dari penjualan perusahaan. Perusahaan dengan penjualan yang relatif stabil dapat memperoleh lebih banyak utang dan dapat menanggung beban tetap yang lebih tinggi dibandingkan dengan perusahaan yang penjualannya tidak stabil. (Brigham \& Houston, 2001) Ukuran sebuah perusahaan sering kali menentukan reputasi dan citranya di mata masyarakat, Perusahaan dengan ukuran besar seperti Indofood sudah dikenal oleh masyarakat dan memiliki citra yang baik dalam pasar mie instan. Belakangan iini Indofood telah melakukan transformasi berubah menjadi perusahaan yang dikenal sebagai perusahaan "Total Food Solutions". Saat ini Indofood dikenal sebagai perusahaan terkemuka di setiap kategori lini bisnisnya. Hal ini terlihat pada tahun 2013 Indomie mendominasi sekitar 70\% dalam pasar mie instan (Tempo, 2013). dengan laba netto penjualan sebesar Rp. 55,62 triliun, Rp. 63,59 triliun pada tahun 2014, Rp. 64,06 triliun pada tahun 2015, Rp. 66,66 triliun pada tahun 2016 dan Rp. 70,19 triliun pada tahun 2017. Dengan besarnya penggunaan utang yang dilakukan Indofood pada tahun 2013 yaitu 4,62 triliun, sebesar 5,06 triliun pada tahun 2014, sebesar 5,97 trilin 5,99 triliun pada tahun 2017 dan sebesar 9,95 triliun pada tahun 2017. Hal ini menunjukan bahwa besar dan kestabilan penjualan perusahaan sebagai citra dari perusahaan dalam memperoleh utang.

Baik atau buruknya citra sebuah perusahaan akan memberikan pengaruh kepada kreditur dalam memberi pinjaman kepada perusahaan. Perusahaan dengan penjualan yang stabil dapat memperoleh lebih banyak, karena dianggap lebih kredibel dibandingkan perusahaan dengan penjualan tidak stabil.

Perusahaan dengan citra yang baik pada umumnya merupakan perusahaan dengan ukuran besar dan perusahaan yang terdiversifikasi, perusahaan ini memiliki penjualan yang relatif stabil dengan jangkauan konsumen yang luas. Sesuai dengan signaling theory, semakin besar perusahaan, semakin banyak informasi yang diharapkan tersedia tentang perusahaan, yang mengurangi asimetri informasi di pasar. Informasi ini akan memberikan sinyal kepada masyarakat maupun kreditur mengenai dan citra perusahaan, yang berdampak kepada kemudahan dan kesulitan sebuah 
perusahaan dalam mendapatkan pinjaman, sehingga akan mempengaruhi keputusan pendanaan perusahaan dalam menggunakan utang (Deesomsak et al., 2004).

Pada saat Graham dan Harvey (2002) melakukan penelitian dengan survei terhadap pelaksanaan praktik pembiayaan yang dilakukan oleh 4.440 perusahaan dan menunjukkan hasil bahwa ukuran perusahaan (firm size) mempunyai pengaruh signifikan terhadap leverage. Perusahaan besar berpeluang pada investasi yang lebih tinggi serta berada pada kebutuhan uang tunai yang lebih tinggi daripada perusahaan yang kecil (Dittmar, 2004). Ketika sebuah perusahaan bertumbuh dalam penjualan yang menjadi proksi firm size, kemampuannya untuk meminjam meningkat, sehingga rasio leverage juga meningkat.

Dalam penelitian ini, untuk melihat pengaruh lebih jelas antara firm size terhadap leverage maka digunakan tiga variabel kontrol. Ketiga variabel kontrol ini, antara lain Asset tangibility, Profitabilitas dan Firm Age. Asset tangibility menjadi salah satu faktor yang mempengaruhi kemudahan dalam melakukan leverage. Asset tangibility dianggap mewakili jaminan riil atau tangible yang dapat ditawarkan kepada kreditor untuk memperoleh utang. Karena itu, pentingnya aset tersebut di antara total aset mempengaruhi tingkat utangnya, yang meningkat bersamaan dengan meningkatnya jaminan yang diberikan oleh perusahaan untuk upaya menyelesaikani kewajibannya yang disebabkan utang (Chung, 1993; Rajan \& Zingales, 1995).

Profitabilitas menjadi salah satu faktor internal yang turut mempengaruhi leverage. Profitabilitas adalah suatu upaya dimana perusahaan memperlihatkan kemampuannya untuk menghasilkan laba pada periode yang ditetapkan. Profitabilitas yang makin meningkat memungkinkan perusahaan untuk menahan labanya menjadi lebih besar. Sesuai dengan pecking order theory dengan laba ditahan yang besar, perusahaan akan lebih memilih menggunakan laba ditahan terlebih dahulu daripada menggunakan utang.

Firm age atau umur perusahaan. Umur perusahaan salah satu faktor yang juga mempengaruhi leverage, Umur perusahaan adalah lamanya sebuah perusahaan berdiri, berkembang dan bertahan dihitung dari akta pendiriannya. Menurut Beatty (1989), sebuah perusahaan yang pendirian usahanya sudah lama, tentunya sudah banyak pengalaman yang diperoleh dari berbagai peristiwa yang dialami. Itulah sebabnya, semakin lama umur perusahaan, akan semakin banyak informasi yang telah diperoleh publik tentang kondisi perusahaan tersebut. Oleh sebab itu perusahaan yang berumur lebih tua akan lebih memilih menggunakan utang karena para kreditor sudah percaya terhadap perusahaan tersebut.

\section{TEORI PENUNJANG}

\section{Struktur modal}

Struktur modal merupakan suatu kombinasi yang khas diantara utang jangka panjang dan ekuitas yang dikerjakan perusahaan dalam upaya untuk pendanaan perusahaannya. Kombinasi ini sebenarnya akan mempengaruhi resiko serta nilai perusahaan (Ross et al., 2013). Brigham dan Houston (2001) menyatakan bahwa suatu struktur modal yang optimal seyogyanya harus berdiri pada situasi keseimbangan diantara risiko dan pengembalian agar terjadi situasi yang akan memaksimumkan harga saham. Alzomaia (2014) menyatakan suatu keputusan tentang struktur modal akan menjadi faktor penting penggunaan dana pada perusahaan, hal ini dikarenakan 
struktur modal yang optimal adalah struktur modal yang sesungguhnya dapat meminimalkan biaya yang dilakukan perusahaan.

\section{Leverage}

Menurut (Gitman \& Zutter, 2012), Leverage adalah penggunaan dari biaya tetap untuk memperbesar tingkat pengembalian pemegang saham. Harris \& Raviv (1991) menjelaskan bahwa peningkatan leverage disebabkan karena meningkatnya nilai fixed asset, adanya non debt tax shields, investment opportunities dan firm size, sedangkan penurunan leverage disebabkan menurunnya risiko (volatility), pengeluaran periklanan, probabilitas kepailitan (bankruptcy), keuntungan dan keunikan produk. Jika rasio dari leveragemengalami peningkatan maka tingkat risiko yang akan dihadapi oleh perusahaan akan meningkat juga, karena saat perusahaan hanya memperoleh keuntungan yang ternyata lebih rendah dari biaya tetap yang dikeluarkannya maka sebenarnya penggunaan leverage pada perusahaan tersebut akan menurunkan keuntungan pemegang saham. Oleh sebab itu kreditor biasanya berusaha mencegah rasio leverage yang tinggi.

Leverage adalah upaya perusahaan dalam melakukan komposisi jangka waktu utang yang digunakan perusahaan. Artinya komposisi dari utang jangka pendek dan utang jangka panjang yang dimanfaatkan perusahaan dalam upaya pendanaannya. Semakin pendek jangka waktu kewajiban finansial, kemungkinan memperpanjang jangka waktu semakin besar sehingga ada biaya yang timbul dalam upaya memperpanjang pemanfaatan utang tersebut yang harus dilakukan dan perusahaan juga kemungkinan akan kesulitan keuangan (menanggung biaya kebangkrutan). Itulah sebabnya, jangka waktu pinjaman yang lebih lama akan membuat perusahaan lebih merasa aman bagi perusahaan (artinya kecil kemungkinan peluang adanya tanggungan terjadinya biaya kebangkrutan).

\section{Firm size}

Pada penelitian yang dilakukan Antoniou et al. (2002), variable size dinyatakan sebagai ukuran perusahaan yang diperoleh dari menghitung nilai logaritma natural penjualan perusahaan. Crutchley dan Hansen (1989) menyatakan bahwa firm size punya pengaruh signifikan dan arah positif terhadap leverage. Hal ini berarti, semakin besar firm size akan menyebabkan pendanaan yang dibutuhkan perusahaan melalui utang akan semakin besar, sehingga perusahaan akan melakukan pendanaan melalui utang. Perusahaan-perusahaan besar akan lebih mudah untuk memperoleh utang ataupun pinjaman dari pihak ketiga, hal ini lebih disebabkan kemampuannya lebih mudah mengakses pihak lain disebakan besarnya ukuran perusahaan mereka atau juga disebabkan jaminan yang dimiliki perusahaan berupa aset bernilai lebih besar dibandingkan perusahaan yang lebih kecil.

\section{Asset tangibility}

Asset Tangibility adalahsuatu kondisi dimana perusahaan memiliki level aset tetap, sedangkan aset tetap yang disebut property, plant, and equipment (PPE) adalah aset yang dibeli atau diperoleh perusahaan untuk diupayakan atau dimanfaatkan secara jangka panjang. Menurut Alzomaia (2014), perusahaan yang mempunyai Asset Tangibility yang besar akan memanfaatkan utang yang lebih besar karena bisa menggunakan Asset Tangibility sebagai bentuk jaminan dalam upaya memperoleh pendanaan melalui utang. Menurut Titman dan Wessels (1988), Asset 
Tangibility merupakan aset berwujud dari suatu perusahaan yang bisa mempengaruhi keputusan pembiayaan perusahaan dan pada umumnya aset berwujud mempunyai tingkat likuiditas yang tinggi. Asset Tangibility yang digunakan sebagai jaminan dapat membantu perusahaan dalam upaya melakukan upaya pelunasan utang apabila perusahaan mengalami kondisi gagal bayar utang maka kreditur akan berupaya mengambil alih Asset Tangibility milik perusahaan sebagai jaminan untuk dalam upaya pembayaran utang ang sudah dipinjam tersebut.

\section{Profitabilitas}

Profitabilitas adalah kemampuan perusahaan dalam memperoleh laba. (Saidi, 2004) Dengan retained earning yang akan menjadi lebih besar, membuat perusahaan cenderung lebih menyukai penggunaan laba ditahan dibandingkan menggunakan utang (Myers,1984). Hal ini menjelaskan dukungan terhadap pecking order theory yang menjelaskan para manajer akan lebih menyukai menggunakan pembiayaan dari laba ditahan artinya dari pendanaan internal, kemudian penggunaan utang, dan pilihan yang paling terakhir, penjualan saham baru. Walaupun diketahui secara teoritis, sumber modal yang dianggap biayanya paling murah dari kesemua pilihan pendanaan tersebut adalah utang, lalu saham preferen, selanjutnya yang paling mahal adalah saham biasa, serta laba ditahan.

\section{Firm age}

Usia pada suatu perusahaan merupakan penanda berapa lama perusahaan telah ada dan terus bertahan. Kieso et al., (2007) berpendapat perusahaan dibentuk dengan harapan jangka waktu yang tidak terbatas atau panjang, tidak bermaksud berdiri hanya beberapa tahun. Umur perusahaan merupakan kondisi dimana perusahaan tersebut melakukan aktivitas operasonalnyai. Perhitungan untuk menentukan Umur perusahaan dimulai dari tanggal berdirinya hingga saat ini. Semakin lama usia perusahaan, akan diperoleh informasi tentang perusahaan tersebut, hal ini dapat meminimkan tingkat uncertainty investor. Suatu Perusahaan yang berdiri lebih lama atau usia panjang dengan pertumbuhannya menjadi perusahaan besar tentunya memiliki banyak investor dan terus bertahan dalam dunia bisnis, sehingga pengungkapan informasi tentang perusahaan menjadi lebih banyakl. Jadi, jika semakin tua umur perusahaan, yang memperlihatkan juga lamanya hubungan antara perusahaan dengan perbankan sebagai mitra pendanaanya, maka akan meminimkan kondisi asimetris informasi diantara perusahaan dan bank. (Petersen, 2006; Rajan \& Zingales, 1995; dan Viviani, 2008)

\section{Pecking Order Theory}

Teori pecking order menjelaskan bahwa perusahaan memiliki urutan-urutan dalam memenuhi kebutuhan pendanaan perusahaan. Perusahaan akan berupaya untuk melakukan pendanaan lewat pembiayaan internal yang dipunyai perusahaan, misalkan dari pembentukan cadangan (misal cadangan pensiun), atau akun-akun aset (penjualan aset), dan dari saldo laba (akumulasi laba ditahan). Berdasarkan teori ini, ketersediaan dana internal jikalau tidak mampu memenuhi kebutuhan dana untuk investasi perusahaan, maka perusahaan bisa bertindak dengan cara mencari sumber pendanaan lain atau sumber eksternal berupa hutang atau saham. Pendanaan dari sumber internal ini menjadi prioritas tertinggi perusahaan dibandingkan pembiayaan sumber eksternal seperti emisi surat hutang maupun pembiayaan dari emisi ekuitas (penjualan saham), hal inilah merupakan upaya menjelaskan bagaimana urutan perusahaan ketika melakukan pemilihan sumber pendanaan bagi perusahaan, Myers (1984) menyatakan keputusan pendanaan 
dalam penjelasan Pecking Order Theory adalah melakukan suatu prosedur urutan pendanaan tertentu melalui pertimbangan aspek- aspek dibawah ini, yaitu:

1. Memilih pembiayaan dari sumber internal untuk pendanaan proyek-proyeknya.

2. Melakukan penyesuaian terhadap target dividend pay-out rasio dengan kesempatan melakukan investasi.

3. Menerapkan Kebijakan dividen yang kaku, Adanya kondisi terjadinya fluktuasi terhadap profitabilitas disertai peluang investasi yang sulit diprediksi membuat akumulasi dana yang dihasilkan melalui aktivitas internal bisa lebih kecil atau besar dibandingkan capital expenditure. Ketika situasi yang dihadapi adalah dana internal lebih besar, dalam hal ini perusahaan akan memanfaatkannya untuk pelunasan utang atau berinvestasi pada investasi jangka pendek melalui marketable securities. Ketika situasi yang terjadi kebalikannya, perusahaan mengalami situasi yang defisit, perusahaan bertindak dengan cara saldo kas dilakukan penurunan atau melakukan pelepasan atau menjual investasi jangka pendeknya atau marketable securities.

4. Ketika sumber daya tambahan diperlukan, perusahaan akan cenderung melakukan pilihan terhadap sumber pendanaan melalui utang baru kemudian sekuritas.

\section{Signalling Theory}

Brigham dan Houston (2006) dalam pernyataanya mengatakan bahwa isyarat atau signal merupakan suatu tindakan yang dilakukan sebuah perusahaan untuk memberikan penanda atau petunjuk untuk investor tentang pandangan manajemen atau dengan kata lain bagaimana pihak manajemen suatu perusahaan bersikap atau memandang prospek terhadap perusahaan mereka di masa yang mendatang.

Signalling theory sesungguhnya memberi penekanan terhadap urgensi sebuah informasi yang dipublikasikan perusahaan akan menjadi sinyal bagi investor dalam upaya mengambil keputusan investasi terhadap perusahaan tersebut. Informasi menjadi titik krusial bagi investor dan pelaku bisnis dalam pilihan keputusannya karena menyediakan catatan atau penjelasan, serta gambaran terhadap situasi atau keadaan masa lalu (historis), situasi saat ini maupun proyeksi keadaan masa yang akan datang agar dapat digunakan oleh investor dan pelaku bisnis sebagai alat untuk menganalisis keputusan investasi. Manajemen berusaha mengungkapkan informasi private yang menurut pertimbangannya sangan diminati oleh para investor dan pemegang saham khususnya informasi tersebut berita baik.

\section{METODOLOGI PENELITIAN}

\section{Gambaran Populasi dan Sampel}

Dalam penelitian ini, populasi yang digunakan adalah seluruh perusahaan manufaktur yang beroperasi di Indonesia. Teknik pengambilan sampel dalam penelitian ini adalah purposive sampling, yaitu teknik pengambilan sampel dari sumber data pertimbangan tertentu dan tidak menyimpang dari ciri-ciri yang ditetapkan (Sugiyono, 2009).

Kriteria pemilihan sampel adalah:

a. Perusahaan yang mempublikasikan laporan keuangan dan laporan tahunan secara lengkap dan tidak melakukan delisting pada periode 2013-2017

b. Perusahaan yang menggunakan mata uang rupiah dalam laporan keuangannya

c. Perusahaan yang memiliki data lengkap terkait dengan variabel penelitian yang dilakukan 


\section{Jenis dan Sumber Data}

Jenis data yang digunakan adalah data sekunder, yaitu data yang diperoleh secara tidak langsung atau diperoleh dari lembaga tertentu. Data bersumber dari Bloomberg dan laporan keuangan dan laporan tahunan perusahaan yang diperoleh dari situs idx.co.id.

\section{Persamaan Regresi}

Model regresi pada penelitian ini adalah sebagai berikut:

Model 1:

a) $\mathrm{TD}=\alpha_{i}+\alpha_{1}$ SIZE $i t+\varepsilon$

b) STDLEV $=\alpha_{i}+\beta_{1}$ SIZE $i t+\varepsilon$

c) $\operatorname{LTDLEV}=\alpha_{i}+\gamma_{1}$ SIZE $i t+\varepsilon$

Model 2:

a) $\mathrm{TD}=\alpha_{\mathrm{i}}+\alpha_{1} \mathrm{SIZE}_{\mathrm{it}}+\alpha_{2} \mathrm{TANG}_{\mathrm{it}}+\alpha_{3} \mathrm{PROF}_{\text {it }}+\alpha_{4} \mathrm{AGE}_{\mathrm{it}}+\varepsilon$

b) $\mathrm{STD}=\alpha_{\mathrm{i}}+\beta_{1} \mathrm{SIZE}_{\mathrm{it}}+\beta_{2} \mathrm{TANG}_{\mathrm{it}}+\beta_{3} \mathrm{PROF}_{\text {it }}+\beta_{4} \mathrm{AGE}_{\mathrm{it}}+\varepsilon$

c) $\mathrm{LTD}=\alpha_{\mathrm{i}}+\gamma_{1} \mathrm{SIZE}_{\mathrm{it}}+\gamma_{2} \mathrm{TANG}_{\text {it }}+\gamma_{3} \mathrm{PROF}_{\text {it }}+\gamma_{4} \mathrm{AGE}_{\text {it }}+\varepsilon$

\section{ANALISA DAN PEMBAHASAN}

\section{Pemilihan Model Terbaik}

Terdapat dua uji yang digunakan untuk menentukan model regresi yang terbaik, yaitu chow test dan hausman test. Pemilihan model terbaik ini dilakukan untuk menentukan model regresi yang tepat untuk digunakan dalam penelitian ini.

\section{Chow Test}

Chow test merupakan uji yang digunakan untuk menentukan model regresi terbaik antara Pooled Least Square/Common Effect Model dan Fixed Effect Model (FEM).

Model 1:

\begin{tabular}{|c|c|c|c|c|}
\hline Variabel Dependen & $\begin{array}{c}\text { Cross-section Chi- } \\
\text { square }\end{array}$ & d.f. & Prob. & Kesimpulan \\
\hline Total Debt leverage & 446.984557 & 41 & 0.0000 & Fixed Effect \\
\hline Short-term leverage & 293.208591 & 41 & 0.0000 & Fixed Effect \\
\hline Long-term leverage & 392.959096 & 41 & 0.0000 & Fixed Effect \\
\hline
\end{tabular}

Model 2:

\begin{tabular}{|c|c|c|c|c|}
\hline Variabel Dependen & $\begin{array}{c}\text { Cross-section Chi- } \\
\text { square }\end{array}$ & d.f. & Prob. & Kesimpulan \\
\hline Total Debt leverage & 419.605090 & 41 & 0.0000 & Fixed Effect \\
\hline Short-term leverage & 296.888454 & 41 & 0.0000 & Fixed Effect \\
\hline Long-term leverage & 347.426933 & 41 & 0.0000 & Fixed Effect \\
\hline
\end{tabular}


Dari hasil chow test pada tabel diatas, diketahui bahwa $p$-value persamaan 1 dan 2 lebih kecil dari $\alpha=5 \%$, sehingga hipotesa nol ditolak. Oleh karena hipotesa nol ditolak, maka model yang lebih tepat adalah Fixed Effect Model (FEM). Dengan demikian maka pengujian model perlu dilanjutkan dengan menggunakan hausman test

\section{Hausman Test}

Hausman test digunakan untuk memilih model analisa regresi terbaik antara Fixed Effect Model (FEM) dan Random Effect Model (REM).

Model 1:

\begin{tabular}{|l|c|c|c|c|}
\hline Variabel Dependen & $\begin{array}{c}\text { Cross-section } \\
\text { Random }\end{array}$ & d.f. & Prob. & Kesimpulan \\
\hline Total Debt leverage & 8.069491 & 1 & 0.0045 & Fixed Effect \\
\hline Short-term leverage & 9.601567 & 1 & 0.0019 & Fixed Effect \\
\hline Long-term leverage & 7.381177 & 1 & 0.0066 & Fixed Effect \\
\hline
\end{tabular}

Model 2:

\begin{tabular}{|l|c|c|c|c|}
\hline Variabel Dependen & $\begin{array}{c}\text { Cross-section } \\
\text { Random }\end{array}$ & d.f. & Prob. & Kesimpulan \\
\hline Total Debt leverage & 12.665187 & 4 & 0.0130 & Fixed Effect \\
\hline Short-term leverage & 10.307379 & 4 & 0.0356 & Fixed Effect \\
\hline Long-term leverage & 15.476257 & 4 & 0.0038 & Fixed Effect \\
\hline
\end{tabular}

Dari hasil Hausman test pada tabel diatas, diketahui bahwa $p$-value 1 dan 2 lebih kecil dari $\alpha=$ $5 \%$, sehingga hipotesis nol ditolak. Oleh karena hipotesa nol ditolak, maka model yang lebih tepat adalah Fixed Effect Model (FEM) untuk persamaan- persamaan tersebut.

\section{Hasil Regresi}

Model 1:

a) $L E V i t=2.79753-0.087128$ SIZEit $+\varepsilon$

b) STDLEVit $=-0.188609-0.012244$ SIZEit $+\varepsilon$

c) LTDLEVit $=1.882747-0.06092 \mathrm{SIZEit}+\varepsilon$

Model 2:

a) $\mathrm{LEV}_{i t}=2.250859-0.060236 \mathrm{SIZE}_{i t}+0.004746 \mathrm{TANG} i t-0.432329 \mathrm{PROF} i t-0.004818 \mathrm{AGE} i t+\varepsilon$

b) STDLEV it $=1.687729+0.019108 \mathrm{SIZE} i t-0.000412 \mathrm{TANG}$ it $-0.191918 \mathrm{PROF}$ it $-0.000277 \mathrm{AGE} i t+\varepsilon$

c) LTDLEV it $=1.523743-0.046644 \mathrm{SIZE} i t+0.002497 \mathrm{TANG} i t-0.272029 \mathrm{PROF} i t-0.000786 \mathrm{AGE} i t+\varepsilon$ 
Uji $t$

\begin{tabular}{|c|c|c|c|c|c|}
\hline & Variabel & Koefisien & t-Statistic & Prob. & Keterangan \\
\hline Total debt leverage & $\begin{array}{l}\text { Firm Size } \\
\text { Constant } \\
\text { R-squared }=0.881704\end{array}$ & $\begin{array}{l}-0.087128 \\
2.79753\end{array}$ & $\begin{array}{l}-3.784153 \\
4.233443\end{array}$ & $\begin{array}{l}0.0002 \\
0.000\end{array}$ & Signifikan \\
\hline Short-term leverage & $\begin{array}{l}\text { Variabel } \\
\text { Firm Size } \\
\text { Constant } \\
\text { R-squared }=0.742476\end{array}$ & $\begin{array}{l}\text { Koefisien } \\
0 \\
3.250154\end{array}$ & $\begin{array}{l}\text { t-Statistic } \\
-5.020934 \\
5.285505\end{array}$ & $\begin{array}{l}\text { Prob. } \\
0.000 \\
0.000\end{array}$ & Signifikan \\
\hline Long-term leverage & $\begin{array}{l}\text { Variabel } \\
\text { Firm Size } \\
\text { Constant } \\
\text { R-squared }=0.846069\end{array}$ & $\begin{array}{l}\text { Koefisien } \\
-0.06092 \\
1.882747\end{array}$ & $\begin{array}{l}\text { t-Statistic } \\
-3.107827 \\
3.346519\end{array}$ & $\begin{array}{l}\text { Prob. } \\
0.0022 \\
0.001\end{array}$ & Signifikan \\
\hline Total debt leverage & $\begin{array}{l}\text { Variabel } \\
\text { Firm Size } \\
\text { Asset Tangibility } \\
\text { Profitabilitas } \\
\text { Firm Age } \\
\text { Constant } \\
\text { R-squared }=0.890731\end{array}$ & $\begin{array}{l}\text { Koefisien } \\
-0.060236 \\
0.004746 \\
-0.432329 \\
-0.004818 \\
2.250859\end{array}$ & $\begin{array}{l}\text { t-Statistic } \\
-2.3647 \\
0.84782 \\
-3.6485 \\
-1.2163 \\
3.27661\end{array}$ & $\begin{array}{l}\text { Prob. } \\
0.0192 \\
0.3978 \\
0.0004 \\
0.2256 \\
0.0013\end{array}$ & $\begin{array}{l}\text { Keterangan } \\
\text { Signifikan } \\
\text { Tidak signifikan } \\
\text { Signifikan } \\
\text { Tidak signifikan } \\
\text { Signifikan }\end{array}$ \\
\hline Short- term leverage & $\begin{array}{l}\text { Variabel } \\
\text { Firm Size } \\
\text { Asset Tangibility } \\
\text { Profitabilitas } \\
\text { Firm Age } \\
\text { Constant } \\
\text { R-squared }=0.747946\end{array}$ & $\begin{array}{l}\text { Koefisien } \\
-0.104994 \\
-0.008405 \\
0.129662 \\
-0.000494 \\
3.191095\end{array}$ & $\begin{array}{l}\text { t-Statistic } \\
-4.3031 \\
-1.5675 \\
1.14238 \\
-0.1302 \\
4.84962\end{array}$ & $\begin{array}{l}\text { Prob. } \\
0 \\
0.1189 \\
0.255 \\
0.8965 \\
0\end{array}$ & $\begin{array}{l}\text { Keterangan } \\
\text { Signifikan } \\
\text { Tidak signifikan } \\
\text { Tidak signifikan } \\
\text { Tidak signifikan } \\
\text { Signifikan }\end{array}$ \\
\hline Long- term leverage & $\begin{array}{l}\text { Variabel } \\
\text { Firm Size } \\
\text { Asset Tangibility } \\
\text { Profitabilitas } \\
\text { Firm Age } \\
\text { Constant } \\
\text { R-squared }=0.853084\end{array}$ & $\begin{array}{l}\text { Koefisien } \\
-0.046644 \\
0.002497 \\
-0.272029 \\
-0.000786 \\
1.523743\end{array}$ & $\begin{array}{l}\text { t-Statistic } \\
-2.1159 \\
0.51541 \\
-2.6527 \\
-0.2292 \\
2.56309\end{array}$ & $\begin{array}{l}\text { Prob. } \\
0.0359 \\
0.607 \\
0.0088 \\
0.819 \\
0.0113\end{array}$ & $\begin{array}{l}\text { Keterangan } \\
\text { Tidak signifikan } \\
\text { Tidak signifikan } \\
\text { Signifikan } \\
\text { Tidak signifikan } \\
\text { Signifikan }\end{array}$ \\
\hline
\end{tabular}

\section{Pembahasan}

\section{Pengaruh Firm Size Terhadap Leverage pada Perusahaan Manufaktur}

Hasil penelitian ini menunjukan bahwa firm size berpengaruh signifikan negatif terhadap total debt leverage, short-term leverage dan long-term leverage. Setelah adanya variabel kontrol, hasil penelitian ini menunjukkan hasil yang sama yaitu firm size berpengaruh signifikan terhadap total debt, short-term- leverage. Namun menunjukan hasil yang berbeda terhadap long-term leverage. Firm size tidak berpengaruh signifikan terhadap long-term leverage.

Perusahaaan dengan sales yang tinggi, cenderung memiliki leverage yang rendah. Hal ini dikarenakan perusahaan dengan sales yang tinggi berpeluang memiliki profitabilitas yang tinggi. Profitabilitas yang tinggi mengindikasikan perusahaan memiliki dana internal yang cukup untuk memenuhi kebutuhan perusahaan baik operasional maupun finansial. Sesuai dengan pecking order theory bahwa perusahaan akan lebih memilih menggunakan pendanaan internal terlebih dahulu, apabila pendanaan internal tidak dapat mencukupi kebutuhan perusahaan maka perusahaan akan menggunakan pendanaan eksternal atau utang.

Sebagai contoh, perusahaan EKAD atau PT. Ekadharma Internasional Tbk. dengan adanya kenaikan firm size yang dihitung dengan proksi sales perusahaan EKAD dari 26.7603 menjadi 27.1903 menyebabkan adanya penurunan leverage EKAD dari18,43\% menjadi 5,76\% (dapat dilihat pada lampuiran Menurut laporan keuangan tahunan EKAD, peningkatan firm size ini dikarenakan meningkatnya permintaan produk dan meningkatnya volume penjualan dengan 
mulai beroperasinya plant baru perseroan dan anak di wilayah Jawa dan luar Jawa, hal ini berkontribusi dalam meningkatnya total penjualan EKAD. Hal ini juga ditunjukan oleh perusahaan JPFA atau PT. Japfa Comfeed Indonesia dengan leverage yang semula $58,69 \%$ menjadi $41,47 \%$ dan firm size semula 30.69 menjadi 31.01. Peningkatan ukuran perusahaan JPFA ini disebabkan oleh profit perusahaan yang meningkat hampir dua kali lipat dikarenakan potensi bisnis perternakan di Indonesia yang besar, pentingnya asupan gizi seimbang bagi kesehatan masyarakat dan juga dikarenakan daya beli masyarakat yang juga meningkat.

Kemudian perusahaan ICBP atau PT Indofood CBP Sukses Makmur dengan leverage yang pada awalnya $11,68 \%$ menjadi $7,45 \%$ dan firm size perusahaan ICBP yang pada awalnya 30,85 menjadi 31,20. Penurunan leverage perusahaan disebabkan oleh peningkatan laba perusahaan, laba perusahaan ini digunakan oleh perusahaan untuk melakukan investasi dan pembayaran utang. Sesuai dengan pecking order theory hal ini akan mempengaruhi pengunaan leverage perusahaan. Perusahaan dengan penjualan yang besar akan memiliki sumber pendanan internal yang tinggi atau besar. Dana internal ini bisa dimanfaatkan atau dipergunakan perusahaan untuk membiayai investasi perusahaan dan digunakan untuk membayar utang perusahaan sehingga akan menurunkan penggunaan utang perusahaan. Hasil penelitian menunjukkan Firm size mempunyai pengaruh signifikan dengan arah yang berlawanan atau negative terhadap short-term leverage. Illustrasi ini juga ditunjukan dari data perusahaan EKAD, bahwa meningkatnya firm size yang dihitung dengan proksi sales perusahaan dari 26.7603 menjadi 27.1903 menyebabkan menurunnya short-term leverage perusahaan yang semula sebesar $37,43 \%$ menjadi 3,69\%. Menurut annual report EKAD, peningkatan penjualan perusahaan sesuai target perusahaan yang disebabkan meningkatnya harga jual produk, sebagian besar laba perusahaan digunakan untuk membayar utang perusahaan. Pengaruh negatif signifikan firm size terhadap short-term leverage juga ditunjukan perusahaan JPFA, utang jangka pendek JPFA yang semula $19,84 \%$ menurun menjadi $3,78 \%$ dengan ukuran perusahaan yang meningkat dari 30,69 menjadi 31,01 .

Perusahaan dengan ukuran yang besar dilihat dari sales perusahaan memiliki aliran kas yang stabil dan berpotensi untuk selalu memiliki ketersediaan dana internal. Sesuai dengan pecking order theory, Perusahaan lebih menyukai sumber pendanaan yang tidak beresiko yang antara lain adalah dana internal. Dana internal ini digunakan untuk membiayai kebutuhan perusahaan, dan untuk membayar utang perusahaan. Hal ini menunjukkan perusahaan dengan penjualan yang meningkat cenderung memilih menggunakan laba ditahan terlebih dahulu dalam memenihi kebutuhan dananya, sehingga penggunaan utang perusahaan akan berkurang. Hasil ini didukung oleh penelitian Cooley dan Quandrini (2001), dan Titman dan Wessels (1988) yang menyatakan bahwa firm size berpengaruh negatif signifikan terhadap leverage.

Sedangkan Firm size tidak berpengaruh signifikan terhadap long-term leverage. Peningkatan penjualan dalam hal ini adalah ukuran perusahaan. Dana internal perusahaan digunakan untuk pembagian dividen kepada pemegang saham, peningkatan produktivitas perusahaan atau ekspansi perusahaan dan terakhir baru digunakan untuk pembayaran utang. Sesuai dengan pecking order theory yaitu jikalau saat sebuah perusahaan ternyata tidak memiliki atau pendanaan melalui sumber internal yang ada ternyata tidaklah mencukupi, maka perusahaan akan bertindak dalam upaya mencari kebutuhan tersebut dan membutuhkan dana eksternal atau berutang. Besar kecilnya ukuran perusahaan tidak menentukan pengunaan utang jangka panjang perusahaan. 
Semua ukuran perusahaan akan melakukan penggunaan utang jangka panjang dalam melakukan investasi, antara lain untuk meningkatkan produktivitas operasi perusahaan dan untuk berekspansi. Untuk dapat meningkatkan produktivitas operasi perusahaan dan berekspansi seringkali membutuhkan dana yang cukup besar, seperti membangun pabrik membeli mesin, baik bagi perusahaan kecil maupun perusahaan besar, sehingga perusahaan membutuhkan pembiayaan dari luar. Itulah sebabnya, Ukuran perusahaan dalam hal ini tidak punya pengaruh terhadap Utang jangka panjang (Long-term Leverage)

\section{Pengaruh Aset Tangibility Terhadap Leverage pada Perusahaan Manufaktur}

Hasil penelitian ini menunjukan Asset tangibility tidak berpengaruh signifikan terhadap Total debt leverage, Short- term leverage dan Long-term leverage perusahaan manufaktur di Indonesia. Banyak atau sedikitnya struktur aktiva tetap yang dimiliki perusahaan yang tidak mempengaruhi kebijakan perusahaan dalam melakukan pendanaan utang. Pendanaan utang yang dilakukan baik jangka panjang maupun jangka pendek akan berhubungan dengan kebutuhan operasional perusahaan, yang berhubungan dengan supply chain perusahaan manufaktur, yang antara lain pemasok, distributor maupun utang usaha yang tidak memerlukan asset tangibility sebagai collateral dalam pinjaman. Asset tangibility bukan satu-satunya tolok ukur kreditur dalam memberikan utang, terutama dalam utang dagang dan utang usaha. Kreditur akan lebih berfokus melihat potensi bayar perusahaan dalam memberikan utang, yang dapat dilihat dari tingkat penjualan atau banyaknya PO (order) yang diterima perusahaan, kredibilitas manajer dan suku bunga. Hal ini didukung oleh penelitian Ezeoha (2008) yang mengatakan bahwa struktur keuangan perusahaan yang didominasi oleh current liabilities pada umumnya tidak selalu membutuhkan collateral deposit.

Hasil penelitian ini memberikan dukungan terhadap penelitian yang dilakukan Titman dan Wessels (1998), Harjanti \& Tandelilin (2007), serta Seftianne \& Handayani (2011) yang juga menunjukkan asset tangibility tidak punya pengaruh terhadap leverage. Hal ini berarti juga tidak menemukan bukti yang mendukung teori yang menyatakan bahwa tangible assets berpengaruh terhadap leverage perusahaan. Selain itu dalam penelitiannya Deemsomsak, et al. (2004) yang menyatakan bahwa asset tangibility yang tinggi tidak berpengaruh terhadap leverage karena asset tangibility pada perusahaan ketergantungannya pada teknologi, sedangkan leverage lebih bergantung bagaiman kebijakan perusahaan tersebut dibuat dan dilakukan, sehingga keterkaitan antara asset tangibility dengan leverage tidak akan terlihat.

\section{Pengaruh Profitabilitas Terhadap Leverage pada Perusahaan Manufaktur}

Hasil penelitian ini menunjukan profitabilitas berpengaruh signifikan negatif terhadap Total Debt Leverage dan Long- term leverage, sedangkan profitabilitas tidak berpengaruh terhadap shortterm leverage Perusahaan Manufaktur di Indonesia. Hal ini menjellaskan bahwa peningkatan profitabilitas pada perusahaan manufaktur ini, selanjutnya berlanjut dengan meningkatnya pendanaan melalui sumber internal yang berarti akan mengurangi ketergantungan pada pendanaan sumber eksternal perusahaan tersebut (dalam hal ini utang perusahaan). Seluruh atau sebagian profit perusahaan digunakan sebagai laba ditahan atau retained earning yang biasanya dimanfaatkan sebagai kompensasi kepada pemegang saham (dividen) atas penggunaan modal sebagai investor. Manajemen akan dihadapkan pada pilihan dalam bentuk membayar laba tersebut dalam hal ini berbentuk dividen atau pilihan dengan menahan dan menginvestasikannya kembali kedalam perusahaan tersebut (Brigham, 2006). Profitabilitas yang terus menerus akan membuat semakin tinggi sehingga meningkatkan sumber pendanaan internal 
perusahaan dan menyebabkan proporsi leverage menjadi relatif kecil. Hal ini sejalan dengan Pecking Order Theory yang menyatakan bahwa perusahaan yang mengalami peningkatan profitabilitas cenderung akan menyisihkan sebagian dari laba bersihnya untuk diinvestasikan ulang, sehingga semakin kecil ketergantungannya terhadap utang. Sedangkan, Profitabilitas tidak berpengaruh terhadap short-term leverage. Dalam rentang waktu yang singkat, besar kecilnya profit perusahaan tidak mempengaruhi penggunaan utang.

Hal ini dikarenakan kreditur tidak hanya melihat potensi pembayaran perusahaan dari profitabilitas, namun juga bisa dari tingkat penjualan perusahaan. Kemudian kecenderungan perusahaan dalam berutang jangka panjang dibandingkan jangka pendek menjadi penyebab profitabilitas tidak berpengaruh signifikan terhadap short-term debt leverage.

\section{Pengaruh Firm Age Terhadap Leverage Pada Perusahaan Manufaktur}

Hasil penelitian ini menunjukan bahwa firm age tidak berpengaruh signifikan terhadap total debt leverage, short-term debt dan long-term debt perusahaan manufaktur. Lamanya usia perusahaan berdiri tidak mempengaruhi perusahaan dalam menggunakan utang. Perusahaan dengan usia berdiri yang lama maupun yang baru berdiri sama-sama menggunakan dana eksternal atau utang untuk memenuhi kebutuhan operasional maupun berekspansi. Sedangkan dana internal perusahaan biasanya digunakan untuk kebutuhan yang lebih mendesak, seperti pembayaran bunga, pembagian dividen.

\section{KESIMPULAN}

Berdasarkan hasil analisis dan pembahasan, maka simpulan yang dapat dikemukakan adalah sebagai berikut: Firm size berpengaruh signifikan terhadap Total debt leverage, Short-term leverage dan Long-term leverage. Dampak firm size berpengaruh signifikan terhadap total debt, short-term- leverage dengan menggunakan variabel kontrol sset tangibility, Profitabilitas dan Firm Age. Hasil ini berbeda ketika firm size tidak berpengaruh signifikan terhadap long-term leverage. Penelitian selanjutnya, sebaiknya menambah variabel pendukung yang relevan seperti asset turnover dan pertumbuhan perusahaan dan menggunakan data yang terdapat pada annual report untuk memperbanyak sampel data penelitian. Penelitian ini menyarankan agar manajemen perusahaan mampu meningkatkan penjualan dengan berekspansi dan meningkatkan kapasitas produksi secara maksimal, sehingga penggunaan utang yang dilakukan perusahaan dapat dioptimalkan.

\section{DAFTAR PUSTAKA}

Alzomaia, T.S.F. (2014). Capital Structure Determinants of Publicly Listed Companies in Saudi Arabia. The International Journal of Business and Finance Research, 8(2), 53-67.

Antoniou, A, Guney, Y. and Paudyal, K. (2002). Determinants of corporate capital structure: Evidence from European Countries. Working paper, University of Durham.

Brigham, E. F. \& Houston, J.F. (2001). Manajemen Keuangan. Edisi Kedelapan Buku 2. Jakarta: Erlangga.

Brigham, E.F. (2006). Dasar-Dasar Manajemen Keuangan, Buku satu, edisi sepuluh. Jakarta: PT. Salemba Empat. 1421-1460.

Beatty, R. P. (1989). Auditor Reputation and the Pricing of Initial Public Offerings. The Accounting Review, 693-709.

Chung, K. H. (1993). Asset characteristic \& corporate debt policy: An empirical test. Journal of Business Finance \& Accounting, 20(1), 83. 
Crutchley, C.E. \& Hansen, R.S. (1989), A test of the agency theory of managerial ownership, corporate leverage, and corporate dividends, Financial Management, 4, 36-46.

Cooley, T. F. and Quadrini, V. (2001). Finansial Markets and Firm Dynamics. American Economic Review, 91 (5): 1286-1310.

Deesomsak, R., Paudyal, K., \& Pescetto, G. (2004). The Determinants of capital structure: Evidence from the Asia Pacific region. Journal of Multinational Financial Management. 14(4-5), 387-405.

Dittmar, A. (2004). Capital structure in corporate spin-offs. Journal of Business, 77 (1), 9-43.

Ezeoha, A.E, (2008). Firm size and corporate financial- leverage choice in a developing economy. Journal of Risk Finance, 9, 351-364.

Gitman, L. J. \& Zutter, C.J. (2012). Principles of Managerial Finance.13th Edition. Global Edition: Pearson Eduation Limited.

Graham, J.R. \& Harvey, C.R. (2002), How do CFOs make capital budgeting and capital structure decisions. Journal of Applied Corporate Finance, 15(1), 8-23

Haris, M., \& Raviv, A. (1991). The theory of capital structure. Journal of Finance, 46, 297-356.

Harjanti, T. T. \& Tandelilin, E. (2007). Pengaruh firm size, tangible asset, growth, oppurtunity, profitability dan business risk pada struktur modal perusahaan manufaktur di Indonesia studi kasus di BEJ. Jurnal Ekonomi dan Bisnis. 1(1), 1-10.

Huyghebaert, N. (2006). On the determinants and dynamics of trade credit use: empirical evidence from business start- ups. Journal of Business Finance \& Accounting, 33, 305-328.

Kieso, D. E., Weygandt, J.J. \& Warfield, T.D. (2007). Akuntansi intermediate. Terjemahan Emil Salim, Jilid 1, Edisi Kesepuluh, Penerbit Erlangga, JakartA

Myers, S.C. (1984), The capital structure puzzle. Journal of Finance, 34 (3), 575- 592.

Pandey, M. (2004). Capital structure, profitability and market structure: evidence from Malaysia. Asia Pacific Journal of Economics and Business, 8(2), 78-98

Petersen, M.F. (2006). Does the Source of Capital Affect Capital Structure. The Review of Financial Studies, 45-79. Tempo.co, 2013. Mi Instan Kontribusi Terbesar Laba Indofood. https://bisnis.tempo. $\mathrm{co} / \mathrm{read} / 533244 / \mathrm{mi}$-instan- kontribusi-terbesar-laba-indofood/full\&view=ok

Rajan, G.R. \& Zingales, L. (1995). What do we know about capital structure: Some evidence from international data. The Journal of Finance, 50(5), 1421-1460.

Ross, S. A., Westerfield, R.W. \& Jordan, B.D. (2013). Fundamentals of Corporate Finance. 10th Edition.McGraw-Hill.

Raviv, M. H. (1991). The Theory of Capital Structure. The Journal of Finance, 46(1), 297-355.

Sugiyono. (2009). Metode Penelitian Kuantitatif, Kualitatif dan $R \& D$. Bandung: Alfabeta.

Seftianne \& Handayani. (2011). Faktor-Faktor yang Mempengaruhi Struktur Modal pada Perusahaan Publik Sektor Manufaktur. Jurnal Bisnis dan Akuntansi, 13(1), 39-56.

Suhaila, M. K., Mahmood, W., \& Mansor, W. (2008). Capital Structure and Firm Characteristics: Some Evidence from Malaysian Companies. MPRA paper 14616, University Library of Munich, Germany.

Saidi. (2004). Faktor-faktor yang Mempengaruhi Struktur Modal Perusahaan Manufaktur Go-public di BEJ tahun 2007-2012. Jurnal Bisnis dan Ekonomi, 11(1), 44-58.

Titman, S. \& Wessels, R. (1988). The determinants of capital structure. Journal of Finance, 43, 1-19.

Tongurai, C. V. (2015). The effect of leverage on performance: Domestically oriented versus internationally oriented firms. Research in International Business and Finance, 34, 265-280

Viviani. (2008). Faktor-faktor yang mempengaruhi struktur modal (studi empiris pada perusahaan industri manufaktur) ditinjau dari filosofi hypotesis pecking order Simposium Nasional: Akuntansi SNA 